\title{
Effect of manufacturing technique on material homogeneity of an implant made of polyetheretherketone
}

\author{
Wiktoria Wojnarowska ${ }^{1), *)}$,Sławomir Miechowicz ${ }^{2)}$, Tomasz Kudasik ${ }^{2)}$ \\ DOI: dx.doi.org/10.14314/polimery.2020.11.3
}

\begin{abstract}
Polymer insert is one of the components of a knee joint endoprosthesis, allowing patients to sustain their mobility. They are mostly made of ultra-high molecular weight polyethylene (UHMWPE) that is not without flaws. Inserts can be manufactured by machining (substractive techniques) or by the use of rapid prototyping techniques (additive manufacturing). In order to increase their strength, is increasingly being considered replacing UHMWPE with polyether ether ketone (PEEK). This material has been analyzed in this work due to the growing interest in using this material for the production of implants. This study contains a comparative analysis of two inserts made using two different methods. Its aim is to verify the effect of the manufacturing technique on material uniformity.
\end{abstract}

Keywords: polyetheretherketone, machining, 3D printing.

\section{Wpływ techniki wytwarzania na zachowanie jednorodności materiału implantu wykonanego z polieteroeteroketonu}

\begin{abstract}
Streszczenie: Jednym z elementów endoprotezy stawu kolanowego, pozwalającej na zachowanie sprawności pacjentów, są wkładki z polimeru. Najczęściej są one wykonywane z polietylenu o ultra dużym ciężarze cząsteczkowym (UHMWPE), który nie jest pozbawiony wad. Wkładki mogą być wytwarzane technikami ubytkowymi lub przyrostowymi. W celu zwiększenia ich wytrzymałości coraz częściej rozważa się zastąpienie UHMWPE polieteroeteroketonem (PEEK). W związku z rosnącym zainteresowaniem aplikacją tego materiału do wytwarzania implantów poddano go badaniom. W pracy dokonano analizy porównawczej wkładek wykonanych z PEEK za pomocą dwóch różnych metod, w tym określono wpływ techniki wytwarzania na jednorodność materiału otrzymanej wkładki.
\end{abstract}

Słowa kluczowe: polieteroeteroketon, obróbka ubytkowa, druk 3D.

Materials used for making bone implants must be biocompatible, non-toxic, bioactive and offer required mechanical properties, such as compressive strength, tensile strength, as well as rigidity and hardness $[1,2]$. The range of materials used for this purpose is very broad, from metals, polymers, ceramics and their composites. Each of them has its strong and weak points.

The knee joint endoprosthesis is one of the widely used implants enabling patients to sustain their motor functions. According to the numerous studies polyethylene parts are the weakest elements of endoprostheses and they determine a durability of endoprosthesis. In the knee endoprostheses, the element that is made of

\footnotetext{
1) Doctoral School of Engineering and Technical Sciences at the Rzeszów University of Technology, al. Powstańcow Warszawy 8, 35-959 Rzeszów, Poland.

2) Rzeszów University of Technology, Faculty of Mechanical Engineering and Aeronautics, Department of Mechanical Engineering, al. Powstańców Warszawy 8, 35-959 Rzeszów, Poland.

*) Author for correspondence: d510@stud.prz.edu.pl
}

polyethylene is a polymer insert (spacer). Kind of material used for frictional elements of endoprostheses has an essential influence on their durability [3]. This has motivated researchers to undertake study on increasing strength properties of inserts.

Polyetheretherketone (PEEK) materials belong to a group of a high-performance thermoplastic polymers and is currently considered as a one of potential materials for making implants. The main advantages that make PEEK increasingly used in tribological components are high mechanical properties, good wear-resistance and heat resistance [4]. The company Invibio Biomaterial Solutions has investigated the application of the material for making implants. An important issue concerning implant production is the selection of the manufacturing method. Polyetheretherketone is a high temperature thermoplastic material, which means that it can be processed using traditional methods such as injection molding or extrusion. PEEK components can be machined by turning or milling. Recently, this material has become one of the materials used in 3D printing with the fused deposition modelling method (FDM). 
Being a polymeric material, PEEK could be printed with 3D printers which can process feedstock available in filament form. One of technology that use material in filament form of required diameter is Fused Deposition Modelling (FDM) also known as Fused Filament Fabrication (FFF) [5]. Process of 3D printing by FDM method consists of printing successive layers of materials that are formed on top of each other (Fig. 1).

That approach allows to fabricate a wide range of structures and complex geometries from three-dimensional (3D) model data [6]. The filament is heated at the nozzle to a temperature nearby melting point and then deposited on the platform or on top of previously printed layers. An essential property of the polymer filament for this method is the thermoplasticity, which allows the wire to fuse together during the 3D printing process. After that, the cooling processes leads the semi-molten material to reassume a solid state. For a complex geometry, a support material is used to support overhanging parts $[5,6]$.

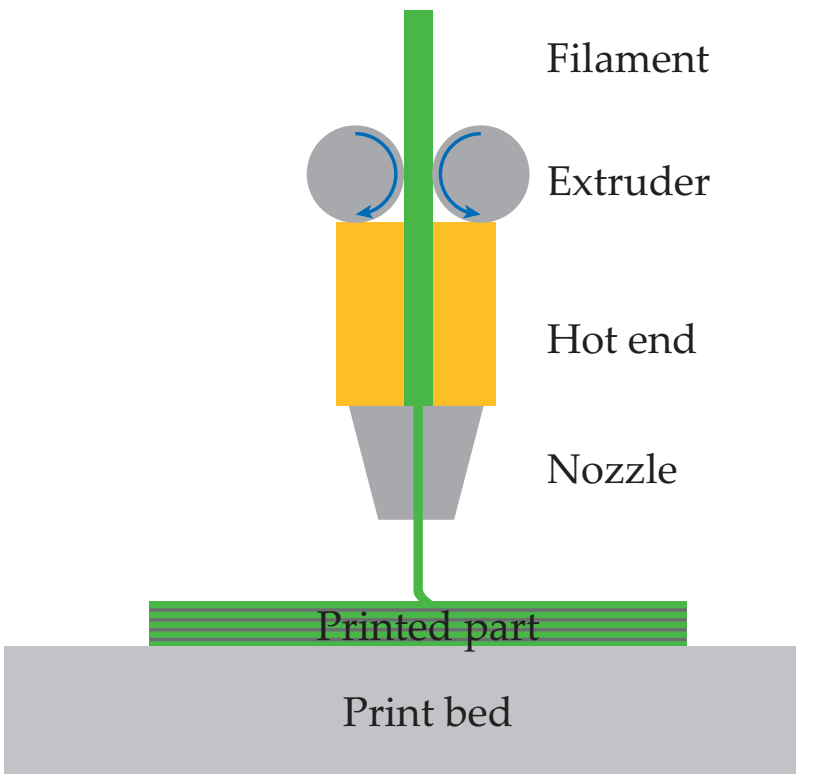

Fig. 1. Schematic diagram of FDM method

In the 3D printing process, there are a number of parameters that can affect the mechanical properties of the finished product. Many scholars have studied the impact of selected printing parameters on the mechanical properties of printed parts, for example Ding et al. studied the effects of nozzle temperature and building orientation on mechanical properties and microstructure of parts printed from PEEK [7]. Wang et al. investigated the effects of various printing parameters, including the printing temperature, printing speed and printing layer thickness on the mechanical properties, microstructure and surface quality of printed PEEK parts [8], the thermal processing conditions impact on crystallinity and mechanical properties were studied by Yang et al. [9].

The method selected to fabricate the implant may determine its physicochemical properties. One of the material properties that can be influenced by the chosen manufacturing method is homogeneity. A homogeneous material means a material that has uniform composition and uniform properties throughout. The mechanical properties of the material are not position functions, i.e. they are the same at every point of the structural element. There are indications that elements made by FDM method are characterized by heterogeneity which can be seen in Fig. 2 . There are visible numerous discontinuities, and even holes.

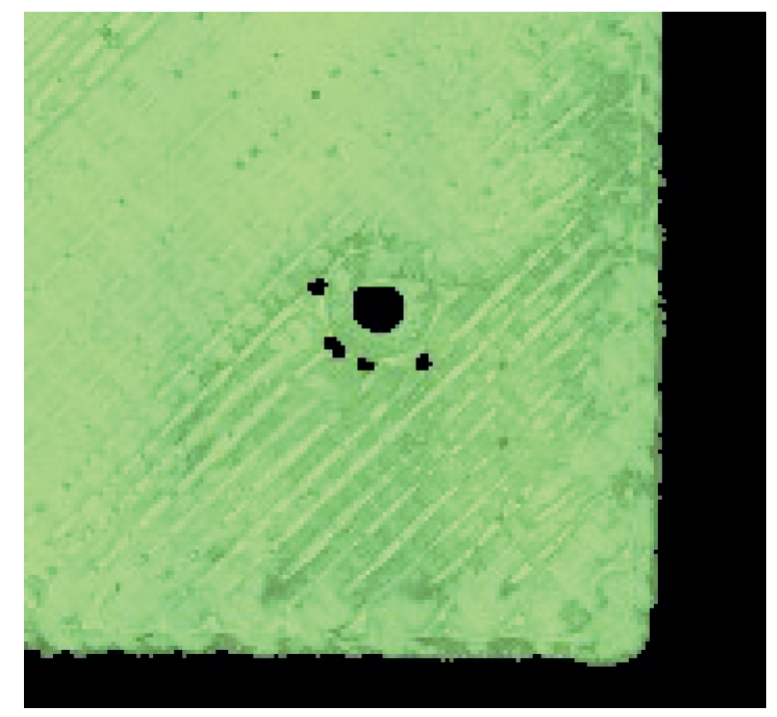

Fig. 2. The microscopic image of 3D printed sample enlarged by $2.5 x$ made with Alicona Infinite Focus Real 3D microscope

The purpose of the present study is to verify the effect of the selected method on the implant's material homogeneity. To achieve this aim, it was performed a literature study and a custom-made insert for a knee joint endoprosthesis was designed, and subsequently fabricated by selected methods.

\section{EXPERIMENTAL PART}

\section{Materials}

PEEK is a semi-crystalline thermoplastic polyaryletherketone (PAEK). Its chemical structure is based on a chain composed of two ether groups (at the core of which are two benzene rings linked to each other by oxygen) and a single ketone group based on a double bond between carbon and oxygen [Formula (I)] [10].

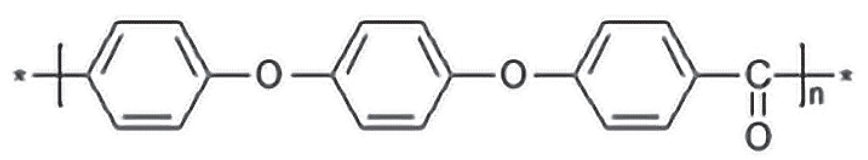

(I)

Such structure ensures high stability of PEEK in high temperatures (even up to $300^{\circ} \mathrm{C}$ ). However, PEEK offers moderate heat resistance in comparison to other members of the family. The processing temperature of the 
polymer ranges from $370-400^{\circ} \mathrm{C}$ [10]. It can be processed by traditional as well as non-standard methods such as 3D printing (Table 1).

T a b l e 1. Selected material processing methods and their applicability in the case of PEEK processing [11]

\begin{tabular}{l|c}
\hline \multicolumn{1}{c}{ Processing method } & Applicability \\
\hline Powder sintering & + \\
Injection molding & + \\
Extrusion & + \\
Machining & + \\
3D FDM printing & + \\
\hline
\end{tabular}

The material is used in biomedical applications thanks to its compatibility with many bioactive substances and its responsiveness to sterilization. PEEK has many applications in medicine because of its unique combination of properties such as temperature resistance, excellent chemical wear and numerous processing capabilities. Due to its radiolucency is possible radiographic assessment using existing diagnostic imaging techniques [12]. Furthermore, PEEK provides features such as biocompatibility, which is very important for materials that will come into contact with human body [13]. What is important, elastic modulus of this material is comparable to cortical bone [14].

\section{Methodology}

In this work, the homogeneity of the medium will be considered due to its strength properties. Identification of isotropy of parts made by additive manufacturing methods was based on literature studies of the articles listed in ScienceDirect. To achieve the research objective, a literature review and bibliometric analysis was done.

In order to compare the insert made from PEEK by different methods, a model of implant was first generated in the SOLIDWORKS software. Physical models for comparative analysis were made on the basis of generated virtual 3D models using the two selected methods: milling and 3D printing. Usually for prototypes or short production runs, it is not economically viable to manufacture an injection molding tool [15]. Patient-Specific Implant (PSI) is usually a unit production. Under such circumstances, it is common to use injection molding or extrusion to form semi-finished product such as rods for subsequent machining by milling or turning. Therefore, the homogeneity of the milled element will depend on how the semi-finished product was fabricated [10].

In the case of machining, the entire process was first designed, which involved defining the shape and dimensions of relevant tools, surfaces to be machined, as well as parameters [16]. The machining process was designed in the SOLIDCAM software, and subsequently performed on a 3-axis LAGUN GNC 5M machine tool.

As for 3D print, the first stage was to program the printing process in the Autodesk Netfabb software. For instance, suitable extruder and build surface temperature were set in the software. Extruder temperature for PEEK should range from 360 to $500^{\circ} \mathrm{C}$, whereas build surface temperature should be minimum $120^{\circ} \mathrm{C}$ [9]. After setting all parameters (Table 2), G-code instructions were saved and transferred to the printer. For 3D printing with PEEK is needed a $3 \mathrm{D}$ printer with specific parameters such as 3D Gence F340.

$\mathrm{T}$ a b l e 2. Some 3D printing process parameters

\begin{tabular}{l|c}
\multicolumn{1}{c|}{ Description } & Value \\
\hline Nozzle temperature, ${ }^{\circ} \mathrm{C}$ & 440 \\
Platform temperature, ${ }^{\circ} \mathrm{C}$ & 130 \\
Layer thickness, $\mathrm{mm}$ & 0.1 \\
Printing speed, $\mathrm{mm} / \mathrm{s}$ & 20 \\
\hline
\end{tabular}

\section{RESULTS AND DISCUSSION}

The literature study was conducted for the following terms: PEEK and „3D printing” or „additive manufacturing" and "mechanical properties". Only research articles and review articles were included. The results of analysis that mainly consider the influence of build orientation of printed elements on their mechanical properties are summarized in Table 3.

T a b l e 3. The summary of analysis

\begin{tabular}{l|l|l}
\hline \multicolumn{1}{c|}{ Parameter } & \multicolumn{1}{c}{ Description } & References \\
\hline Tensile & $\begin{array}{l}\text { The best tensile properties are obta- } \\
\text { ined when filaments are oriented } \\
\text { longitudinally and parallel to the } \\
\text { loading direction. The worst ten- } \\
\text { sile properties are obtained when } \\
\text { the samples are loaded along the } \\
\text { build direction due to weak inter } \\
\text { layer bonding. }\end{array}$ & [7, 17-20] \\
Flexural & $\begin{array}{l}\text { Flexural strength decreases when } \\
\text { the layer thickness decreases. In } \\
\text { some researches, it was found that } \\
\text { the flexural properties followed the } \\
\text { same trend as those of tensile pro- } \\
\text { perties. The best flexural proper- } \\
\text { ties are obtained when filaments } \\
\text { are oriented longitudinally and } \\
\text { parallel to the loading direction. } \\
\text { In some study, it was investigated } \\
\text { that the flexural strength of hori- } \\
\text { zontal printed specimens is slightly } \\
\text { higher than that of vertical printed } \\
\text { specimens. }\end{array}$ & [7, 8, 17-20] \\
\hline $\begin{array}{l}\text { Parts that are printed in horizontal } \\
\text { mode obtain better impact strength } \\
\text { than printed in vertical mode. }\end{array}$ & [7] \\
\hline
\end{tabular}

It can be concluded that printed elements are characterized by high anisotropy. Mechanical anisotropy poses the main problem in additively manufactured parts $[17,21]$. Among all methods of additive manufacturing, the largest anisotropy occurs for parts made using the FDM method and is about 50\% [17]. 


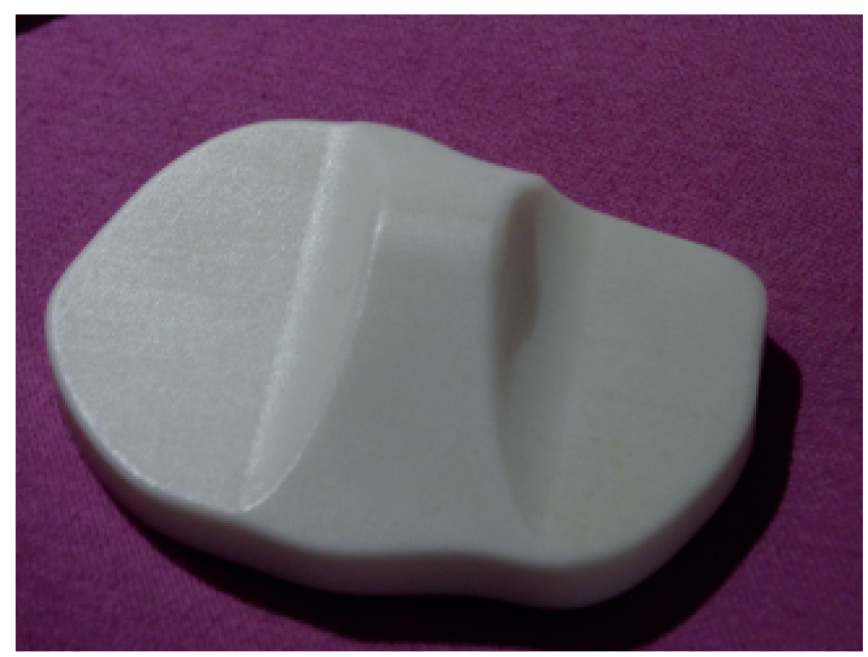

Fig. 3. Model made by using milling machine

Injection molding in comparison with FDM introduced external pressure, which improves the density of parts and reduces internal defects. Many splinter features appear in the rapid propagation zone of injection molded PEEK which suggests good fracture toughness. Printed PEEK characterizes of the inferior toughness than injection molded PEEK. Owing to that occurs brittle fracture in the printed parts [8]. The study performed by Vaezi et al. demonstrated that the 3D printed did not outperform injection molded parts despite using a professional graded industrial FDM machine [14]. All properties of PEEK can reach about $80 \%$ of injection molding parts [7]. However, anisotropy is also present in injection molded parts. In individual zones of molded piece exist some diversity of morphology which could cause the diversification of the physical properties. Impact on mechanical properties of molded parts has also the macromolecule packing density, which is different at the beginning and the end of flow of plastic [22].

In order to perform comparative analysis, there were prepared two models: one by machining, in this particular case by milling (Fig. 3) and one was fabricated using a FDM-type printer (Fig. 4).

The comparative analysis of both models was based on visual inspection. It was found that with the standard production techniques, the surface structure of machined part is inert and smooth, while with FDM 3D printing is more rough. Layer thickness is a key factor in determining the dimensional accuracy and surface roughness of printed parts. Theoretically, if the layer height were small enough, the surface of the sample should be smooth. However, currently the minimum layer size is in the order of $100 \mu \mathrm{m}$ [23]. In vivo studies on bone apposition to implants have demonstrated that rougher surfaces promote bone formation whereas smoother surfaces tend to promote a fibrous interface [24]. However, on the surface of the insert made by 3D were visible structural discontinuity lines. Any surface defects or local surface delamination may have negative effect on the living organism after implantation. One of negative effect of such

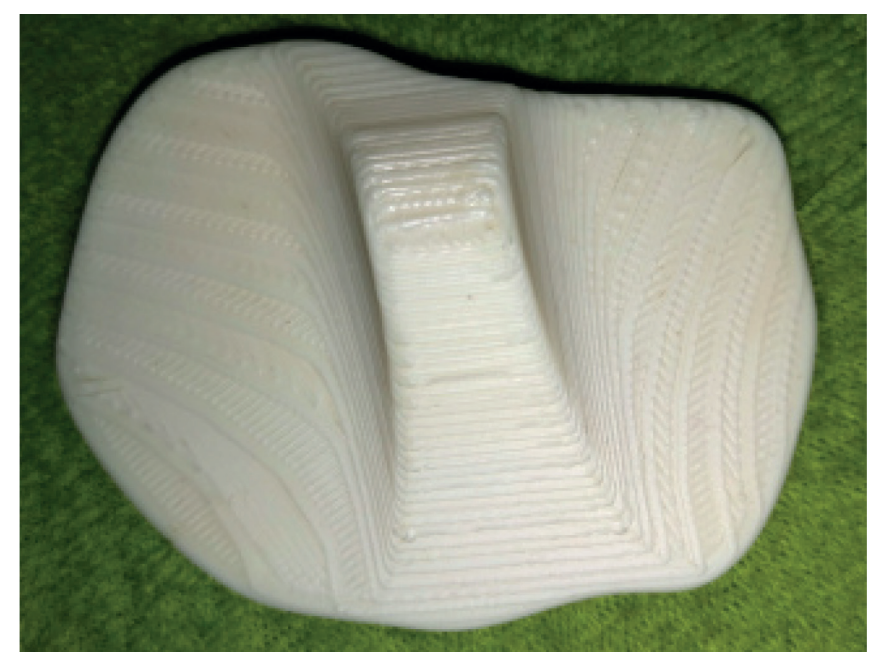

Fig. 4. Model made by FDM technique

defects is increased risk of tissue inflammation [25]. Furthermore, it is not certain that the individual layers have been well joined together. This may result in delamination of the model or even detachment of some of its fragments. To improve the interlayer adhesion between the layers could be use a method developed by Shaffer $e t$ $a l$. In this method, printed parts are exposed to ionizing radiation what increases the strength of parts and decreases their anisotropy [26].

\section{SUMMARY}

Machining can ensure material homogeneity in a model. Implants made using this technique are more likely to meet the requirements of the ISO 10993 standard for medical products $[25,27,28]$. Therefore, subtractive manufacturing techniques are used to make models designed to be implanted in a living organism. In the case of models made by additive manufacturing, a consent of the Bioethics Committee is required to perform the procedure as part of a clinical trial [25]. It is necessary to obtain a full medical certification of device produced by machine what is dependent upon its geometry and application [5]. Today, additive techniques do not guarantee the required homogeneity in the reproduction of anatomical structures. To obtain adequate level of homogeneity, it is required special treatment, e.g. as proposed by Schaffer et al. [26].

In the case of implants, the economic aspect is also significant. PEEK is several times as expensive as the currently used UHMWPE, which influences the final price of the implant.

\section{REFERENCES}

[1] Marciniak J.: „Biomateriały”, Wydawnictwo Politechniki Śląskiej, Gliwice 2013.

[2] Henshaw F., Karasouli E., King R. et al.: BMJ Open 2018, 8, 1 .

http://dx.doi.org/10.1136/bmjopen-2018-021650 
[3] Gierzyńska-Dolna M.: Engineering of Biomaterials 2002, 23-25, 13.

[4] Shijun Ji, Changrui Sun, Ji Zhao et al:: Materials 2015, 8, 4118 . https://doi.org/10.3390/ma8074118

[5] Singh S., Prakash Ch., Ramakrishna S.: European Polymer Journal 2019, 114, 234. https://doi:10.1016/j.eurpolymj.2019.02.035

[6] Ngo T.D., Kashani A., Imbalzano G. et al.: Composites Part B 2018, 143, 172. https://doi.org/10.1016/j.compositesb.2018.02.012

[7] Ding S., Zou B., Wang P. et al.: Polymer Testing 2019, 78, 105498 . https://doi.org/10.1016/j.polymertesting.2019.105948

[8] Wang P., Zou B., Xiao H. et al.: Journal of Materials Processing Technology 2019, 271, 62. https://doi.org/10.1016/j.jmatprotec.2019.03.016

[9] Yang Ch., Tian X., Li D. et al.: Journal of Materials Processing Technology 2017, 248, 1. https://doi.org/10.1016/j.jmatprotec.2017.04.027

[10] Kaczmar J.W., Trzaska O.: Tworzywa sztuczne w przemyśle 2011, 4, 34.

[11] "PEEK Biomaterials Handbook", 2nd edition (Ed. Kurtz S.M.), William Andrew, Amsterdam 2019. https://doi.org/10.1016/C2016-0-02479-8

[12] Kurtz S., Devine J.: Biomaterials 2007, 28, 4845. https://doi.org/10.1016/j.biomaterials.2007.07.013

[13] Haleem A., Javaid M.: Clinical Epidemiology and Global Health 2019, 7, 571. https://doi.org/10.1016/j.cegh.2019.01.003

[14] Vaezi M., Yang S.: Virtual and Physical Prototyping 2015, 10, 123. https://doi.org/10.1080/17452759.2015.1097053

[15] Franchetti M., Kress C.: International Journal of Advanced Manufacturing Technology 2016, 88, 2573. https://doi.org/10.1007/s00170-016-8968-7

[16] Dietrich M., Domański J., Granowski R. et al.: „Biocybernetyka i Inżynieria Biomedyczna 2000,
Vol. 5: Biomechanika i inżynieria rehabilitacyjna", Akademicka Oficyna Wydawnicza EXIT, Warszawa 2004, pp. 931-956.

[17] Dizon J.R.C., Espera A.H., Chen Q. et al.: Additive Manufacturing 2018, 20, 44.

https://doi.org/10.1016/j.addma.2017.12.002

[18] Arif M.F., Kumar S., Varadarajan K.M. et al.: Materials $\mathcal{E}$ Design 2018, 146, 249. https://doi.org/10.1016/j.matdes.2018.03.015

[19] Jaisingh Sheoran A., Kumar H.: Materials Today: Proceedings 2020, 21, 1659. https://doi.org/10.1016/j.matpr.2019.11.296

[20] Popescu D., Zapciu A., Amza C. et al.: Polymer Testing 2018, 69, 157. https://doi.org/10.1016/j.polymertesting.2018.05.020

[21] Poelma J., Rolland J.: Science 2017, 358, 1384. https://doi.org/10.1126/science.aaq1351

[22] Postawa P., Gnatowski A.: Journal of Achievements in Materials and Manufacturing Engineering 2007, 23, 35. http://jamme.acmsse.h2.pl/papers_vol23_2/1070.pdf

[23] Turner B.N., Gold S.A.: Rapid Prototyping Journal 2015, $21,250$. https://doi.org/10.1108/RPJ-02-2013-0017

[24] Schwartz Z., Boyan B.D.: Journal of Cellular Biochemistry 1994, 56, 340. https://doi.org/10.1002/jcb.240560310

[25] Walkowiak B.: Engineering of Biomaterials 2004, 38-42, 200.

[26] Shaffer S., Yang K., Vargas J. et al.: Polymer 2014, 55, 5969. https://doi.org/10.1016/j.polymer.2014.07.054

[27] Kozakiewicz M., Elgalal M., Walkowiak B. et al.: Journal of Cranio-Maxillo-Facial Surgery 2013, 41, 282.

[28] ISO 10993: Biological evaluation of medical devices. The International Organization for Standardization. Revised version 19 V 2020.

\section{Rapid Communications}

Przypominamy Autorom, że publikujemy artykuły typu Rapid Communications - prace oryginalne wyłącznie w języku angielskim (o objętości 4-5 stron maszynopisu z podwójną interlinią, zawierające 2-3 rysunki lub 1-2 tabele), którym umożliwiamy szybką ścieżkę druku (do 3 miesięcy od chwili ich otrzymania przez Redakcję). Artykuł należy przygotować wg wymagań redakcyjnych zamieszczonych we wskazówkach dla P.T. Autorów.

We remind Authors that we publish articles of the Rapid Communications type - the original papers, in English only (with a volume of 4-5 pages of double-spaced typescript, containing 2-3 figures or 1-2 tables), which allow a fast print path (up to 3 months from when they are received by the Editorial Board). The article should be prepared according to the editorial requirements included in the Guide for Authors. 